\title{
Diversitas Genetika dan Identifikasi Jenis Kelamin Burung Pelikan (Pelecanus conspicillatus Temminck, 1824) di Penangkaran Taman Margasatwa Ragunan Jakarta \\ [Genetic Diversity and Sex Identification of Pelicans (Pelecanus conspicillatus Temminck, 1824) in the Captivity of Ragunan Zoo, Jakarta]
}

\author{
Anik Budhi Dharmayanthi ${ }^{1 *}$, Achmad Muchsinin $^{2}$, Afriana Pulungan $^{2}, \&$ \\ Moch Syamsul Arifin Zein ${ }^{1 *}$ \\ ${ }^{1)}$ Pusat Penelitian Biologi, Lembaga Ilmu Pengetahuan Indonesia, Jl. Raya Jakarta-Bogor Km 46, Cibinong 16911 \\ ${ }^{2)}$ Taman Margasatwa Ragunan, Jakarta, Jl. Harsono RM. No. 1, Ragunan, Pasar Minggu,Jakarta Selatan 12550 \\ *Email : anik.budhi.dharmayanthi@gmail.com; zein_genetic@yahoo.com
}

Memasukkan: Februari 2021, Diterima: Mei 2021

\begin{abstract}
Pelicans (Pelecanus conspicillatus) is one of the wild species that have a widely distribution. This bird has been successfully bred in Ragunan Zoo, Jakarta. The indicator of inbreeding in the captive population is shown by the decrease of nucleotide diversity and number of haplotypes. The result of genetic diversity analysis using Dloop fragment sequences showed low genetic diversity with nucleotide diversity $(p)=0.00064 \pm 0.00010$ and haplotype diversity $(\mathrm{Hd})=0.532 \pm 0.061$ in Pelecanus conspicillatus populations in the Ragunan Zoo. However, negative Fu's Fs value $(-3,246)$ indicates population expansion. We found that there were seven haplotypes in bird populations in the captivity: haplotype 1, 2 and 3 consist of 43 individuals $(65.15 \%)$, five individuals $(7.57 \%)$, and 14 individuals $(21.21 \%)$, respectively. For each haplotype 4, 5, 6 and 7 is only represented by one individual of Pelecanus conspicillatus (1.51\%). The sex ratio of males to females is $1: 8.86$ with four males identified as haplotype 1, and one male on haplotypes 3, 5 and 7, respectively. Genetic diversity data of the population is an important way for designing long-term plans and goals in efforts to maintain genetic diversity of the Pelecanus conspicillatus population in captivity.
\end{abstract}

Keywords: Pelecanus conspicillatus, diversity, sex identification

\section{ABSTRAK}

Burung pelikan (Pelecanus conspicillatus) merupakan salah satu hidupan liar yang memiliki sebaran luas. Burung ini telah sukses berkembang biak di Taman Margasatwa Ragunan, Jakarta. Indikator terjadi perkawinan antar keluarga dekat (inbreeding) dalam populasi penangkaran ditunjukkan dengan menurunnya diversitas nukleotida dan jumlah haplotipe. Hasil analisis keragaman genetik dengan menggunakan sekuen fragment Dloop terhadap 66 Pelecanus conspicillatus di penangkaran Taman Margasatwa Ragunan menunjukkan keragaman genetik rendah (diversitas nukleotida (pi) $=0,00064 \pm 0,00010$ dan diversitas haplotipe (Hd) $=0,532 \pm 0,061)$. Nilai Fu's Fs negatif $(-3,246)$ merupakan indikator terjadinya ekspansi populasi. Populasi burung di penangkaran terdapat 7 haplotipe: haplotipe 1, 2 dan 3 masing-masing terdiri dari 43 ekor(65,15\%), 5 ekor(7,57\%) dan 14 ekor(21,21\%), sedangkan haplotipe 4, 5, 6, dan 7 masing-masing ditemukan hanya 1 individu Pelecanus conspicillatus (1,51\%). Rasio seksual jantan dan betina yaitu 1:8,86 dengan empat jantan teridentifikasi sebagai haplotipe 1, dan masing-masing satu jantan pada haplotipe 3, 5 dan 7. Data keragaman genetik dari populasi merupakan langkah awal penting untuk merancang rencana breeding dan tujuan jangka panjang dalam usaha menjaga keragaman genetik dari populasi Pelecanus conspicillatus di penangkaran.

Kata Kunci: Pelecanus conspicillatus, diversitas, identifikasi seksual

\section{PENDAHULUAN}

Burung pelikan Australia (Pelecanus conspicillatus) merupakan salah satu dari tujuh spesies pelican di dunia. Sebaran burung ini meliputi pedalaman dan pesisir perairan Australia, New Guinea, dan Indonesia bagian barat dan sesekali terlihat di New Zealand dan bagian barat kepulauan Pasifik (Voous 1962; Boles 1994). Burung pelikan didominasi warna putih dengan sayap hitam dan paruh merah muda dan tercatat memiliki paruh terpanjang dari semua burung yang ada saat ini (Marchant dan Higgins, 1990). Di Indonesia sebaran burung pelikan meliputi Nusa tenggara, Sulawesi, Maluku, dan Papua. Spesies ini keberadaannya di wilayah Indonesia sebagai Native Non Breeding (BirdLife International 2020). Secara global, populasi dari semua spesies burung pelikan dipengaruhi oleh faktor-faktor utama yaitu menurunnya pasokan 
ikan karena penangkapan yang berlebihan atau terjadi polusi air, perusakan habitat, dan efek langsung dari aktivitas manusia seperti gangguan pada koloni tempat bersarang, serta perburuan dan pemusnahan yang dilakukan manusia (Donald 2007).

Semua spesies burung pelikan berkembang biak dengan mudah di kebun binatang, yang berpotensi berguna untuk pengelolaan konservasi (Crivelli \& Schreiber, 1984). Penangkaran hidupan liar secara ex-situ dapat menjadi faktor penting sebagai salah satu langkah pengawetan spesies. Lembaga konservasi seperti kebun binatang di beberapa lokasi di Indonesia banyak yang telah sukses melakukan penangkaran hidupan liar. Program konservasi ex-situ burung pelikan ( $P$. conspicillatus) telah berhasil dilakukan di Taman Margasatwa Ragunan Jakarta. Langkah pertama adalah melakukan identifikasi jenis kelamin sebagai salah satu faktor penting dalam keberhasilan program konservasi ex-situ. Namun, terkadang tidak mudah untuk mengidentifikasi jenis kelamin dalam kelompok taksonomi tertentu. Pada burung dimorfik sangat mudah untuk membedakan antara jantan dan betina, tetapi banyak spesies burung tidak menunjukkan dimorfisme seksual. Pengukuran morfologis dan penentuan berdasar perilaku tidak selalu dapat diandalkan, hanya pada beberapa burung dewasa dapat digolongkan berdasarkan analisis morfometri dari hubungan kuantitatif antar jenis kelamin dan ukuran tubuh atau warna bulu. Namun demikian sebagian besar yaitu sekitar $60 \%$ spesies burung dewasa tidak memiliki dimorfisme seksual (Rudaya et al. 2020). Para peneliti telah banyak memberi informasi dalam identifikasi jenis kelamin burung berdasarkan ekologi dan perilaku (Helander et al. 2007), selain itu juga memberikan wawasan berharga tentang strategi pemuliaan, program konservasi, dan pengelolaan penangkaran (Helander et al. 2007; Garcia et al. 2009; Naim et al. 2011).

Saat ini identifikasi jenis kelamin dapat menggunakan teknik DNA molekuler. Gen Chromodomain helicase DNA binding (CHD) telah berhasil diaplikasikan pada spesies burung di penangkaran (Ito et al. 2003; Sacchi et al. 2004; Lee et al. 2007, 2010; Cakmak et al. 2017. Purwaningrum et al. 2019; Osman et al.
2020). Disain primer $2550 \mathrm{~F} / 2718 \mathrm{R}$ memiliki target di dua area ekson diantara intron karena memiliki urutan basa nitrogen yang mirip pada banyak spesies dibandingkan dengan disain primer lain (Fridolfsson \& Ellegren 1999). Hasil identifikasi jenis kelamin akan sangat mendukung program penangkaran sehingga dapat ditentukan sex ratio yang optimal pada setiap kandang.

Selanjutnya, penelitian terkait keragaman genetik burung-burung Indonesia belum banyak diketahui atau hanya dilakukan pada beberapa jenis seperti burung Kakatua Putih (Cacatua alba dan C. moluccensis) (Astuti 2011), Pijantung Kecil (Arachnothera longirostra) (prijono dkk 2017), Betet Jawa (Psittacula alexandri alexandri) (Astute 2017). Oleh sebab itu informasi keragaman genetik hidupan liar lainnya terutama yang potensial menjadi burung yang di tangkarkan secara ex-situ perlu diperhatikan. Populasi kecil dalam penangkaran akan memicu terjadi perkawinan antar kerabat dekat yang mengakibatkan terjadi penurunan keragaman genetik. Indikator terjadi silang dalam (inbreeding) dalam populasi ditunjukkan dengan menurunnya diversitas nukleotida dan haplotipe (Jiang et al. 2005). Keragaman genetik menjadi topik penting dalam kegiatan konservasi (Avise 1994), oleh sebab itu data keragaman nukleotida dan haplotipe menjadi keharusan dalam usaha pemanfaatan hidupan liar secara berkelanjutan. Data awal keragaman genetik merupakan langkah penting membuat rencana breeding dan tujuan jangka panjang, yaitu menjaga keragaman genetik dari populasi dalam penangkaran ( $\mathrm{Li}$ et al. 2008). Hal ini dalam usaha mempertahankan persistensi jangka panjang burung pelikan dalam penangkaran $e x$ situ.

Pada penelitian ini akan dilakukan identifikasi jenis kelamin dengan teknik DNA molekuler dengan menggunakan primer $2550 \mathrm{~F} /$ 2718R dan analisis keragaman sekuen D-loop DNA mitokondria untuk mengetahui keragaman genetika terhadap populasi burung pelikan di penangkaran ex-situ Taman Margasatwa Ragunan, Jakarta. Hal ini bertujuan agar dapat dilakukan program penangkaran burung pelikan secara terarah untuk meningkatkan diversitas genetika dari populasi pelikan di penangkaran $e x$-situ. Variasi genetik tinggi dari suatu populasi merupakan dasar baik untuk pengembangan penangkaran burung pelikan secara berkelanjutan. Peningkatan hasil penangkaran pelikan sangat mungkin dilakukan dan dibutuhkan untuk 
keperluan konservasi atau pemanfaatan yang berkelanjutan. Berbagai faktor keragaman genetik harus dipertimbangkan agar penangkaran burung pelikan secara ex-situ dapat dilakukan lebih baik.

\section{BAHAN DAN CARA KERJA}

Sebanyak 69 individu burung pelikan digunakan dalam penelitian ini dari penangkaran ex-situ Taman Margasatwa Ragunan. Burung dipelihara di kandang penangkaran yang dibuat secara terbuka dilengkapi dengan kolam tempat bermain, sehingga memungkinkan setiap individu mencari pasangannya sendiri di waktu musim kawin. Material genetik berupa darah diawetkan dengan menggunakan alkohol absolut 96\% (pure grade). Setiap individu diperiksa kode microchip sebelum diambil darah yang akan digunakan sebagai material DNA yang akan dianalisis. Ekstraksi DNA dilakukan dengan metoda Fenol-Chloroform (Sambrook et al. 1989). Genomik DNA kemudian digunakan untuk identifikasi jenis kelamin dan amplifikasi fragment D-loop DNA mitokondria.

Identifikasi jenis kelamin terhadap 69 burung pelikan dilakukan dengan menggunakan sepasang primer 2550F (5'-GTT ACT GAT TCG TCT ACG AGA-3') dan 2718R (5'-ATT GAA ATG ATC CAG TGC TTG- 3') (Fridolfsson \& Ellegren 1999). Reaksi PCR dilakukan dalam volume total $15 \mu \mathrm{l}$ dimana reaksi akhir mengandung $0,2 \mathrm{mM}$ dNTP, 0,3 pmol dari masing-masing primer, $2,5 \mathrm{mM} \mathrm{MgCl} 2,0,5$ Unit Taq DNA polimerase (10 mM Tris- $\mathrm{HCl} \mathrm{pH} 8,3$ dan $50 \mathrm{mM} \mathrm{KCl}$ ), dan $0,3 \mathrm{mg} / \mathrm{ml}$ BSA. Tips filter merek Extragen digunakan pada proses pencampuran reaksi. Reaksi PCR dilakukan pada mesin Thermocycler Gene Amp* system PCR 9700 (Applied Biosystem, USA). Kondisi PCR diawali dengan denaturasi awal pada suhu $94^{\circ} \mathrm{C}$ selama 5 menit, kemudian 30 siklus dengan denaturasi selama 45 detik pada $94^{\circ} \mathrm{C}$, annealing selama 45 detik pada $46^{\circ} \mathrm{C}$, dan ekstensi selama 90 detik pada $72^{\circ} \mathrm{C}$. Ekstensi akhir pada suhu $72^{\circ} \mathrm{C}$ selama 10 menit. Produk PCR dipisahkan oleh elektroforesis gel agarosa $2 \%$ dengan bufer TAE. Pewarnaan dengan menggunakan gelred dan marker 100 bp sebagai penanda ukuran secara berurutan untuk mengidentifikasi pita $\mathrm{Z}$ dan $\mathrm{W}$ yang berhasil diamplifikasi. Hasil elektroforosis kemudian dilihat menggunakan ultraviolet (UV) transilluminator. Pola pita yang khas digunakan untuk mengidentifikasi jenis kelamin burung yang diperiksa dengan membandingkan kontrol jantan dan betina.

Amplifikasi target D-loop DNA mitokondria menggunakan primer TgLu-70F (CAT ATA CAT TAC ATC CAT TC) dan Cytb-R (GGT GAA GTA GCT GAG GGA GGC TAA TTG) (Geary et al. 2017), campuran PCR yaitu sampel DNA 40ng, KOD One 2x (Toyobo), $0,75 \mathrm{ml}$ primer TgLu-70F/Cytb-R masing-masing 10pmol dalam total volume $25 \mathrm{~mL}$. Kondisi PCR: denaturasi $94^{\circ} \mathrm{C}$ selama 1 menit, annealing $50^{\circ} \mathrm{C}$ selama 90 detik, ekstensi $72^{\circ} \mathrm{C}$ selama 90 detik sebanyak 5 siklus dilanjutkan dengan denaturasi $94^{\circ} \mathrm{C}$ selama 1 menit, anneling $56^{\circ} \mathrm{C}$ selama 90 detik, ekstensi $72^{\circ} \mathrm{C}$ selama 90 detik sebanyak 35 siklus, elongasi akhir pada $72^{\circ} \mathrm{C}$ selama 5 menit. PCR kemudian di sekuen menggunakan jasa layanan sekuen $1^{\text {st }}$ base, Singapura. Sekuen Dloop DNA mitochondria dengan panjang fragmen $1007 \mathrm{bp}$, kemudian dilakukan editing dan disejajarkan dengan menggunakan perangkat lunak Geneious Prime 2021.1.1 (https:// www.geneious.com). Polimorfisme DNA meliputi diversitas haplotipe (Hd) dan diversitas nukleotida (Pi), serta uji Fu dan Li (1993), uji TAJIMA (1989) dilakukan menggunakan DnaSP versi 6 (Rozas et al. 2017). Pohon filogenetik dikonstruksi berdasarkan metode neighbour joining dengan bootstrap 1000 menggunakan MEGA 7.0.

\section{HASIL}

\section{Identifikasi Jenis Kelamin}

Amplifikasi sepasang primer $2550 \mathrm{~F}$ dan 2718R (Fridolfsson \& Ellegren 1999) telah berhasil dilakukan terhadap burung pelikan $(P$. conspicillatus). Visualisasi hasil amplifikasi gen Chromodomain helicase DNA binding (CHD) pada kromosom $\mathrm{Z}$ dan kromosom $\mathrm{W}$ dan di elektroforesis dengan $2 \%$ gel agarose $(\mathrm{M}=$ Marker 100 , satu pita $=\widehat{0}$ dan dua pita $=$ q) dapat dilihat jelas pada Gambar 1. Hasil identifikasi jenis kelamin dapat dilihat secara lengkap pada Tabel 1. Identifikasi jenis kelamin pada 69 burung pelican dalam penangkaran ex-situ di Taman Margasatwa Ragunan, Jakarta, menunjukkan 7 
individu sebagai jantan dan 62 individu burung lainnya berjenis kelamin betina (Tabel 1). Hasil tersebut menunjukkan bahwa perbandingan jantan dan betina burung pelikan di penangkaran ex-situ Taman Marga Satwa Ragunan adalah 1:8,86.

\section{Keragaman Genetik}

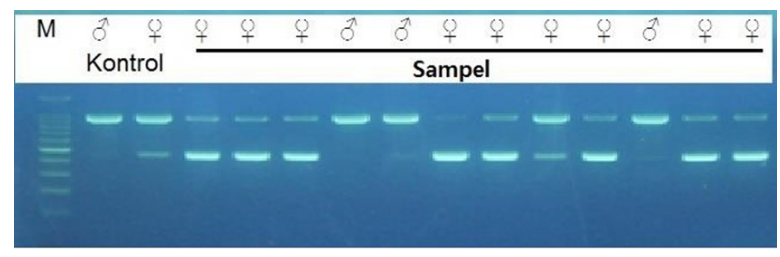

Gambar 1. Visualisasi hasil amplifikasi gen Chromodomain helicase DNA binding (CHD) pada kromosom $\mathrm{Z}$ dan kromosom $\mathrm{W}$ dengan $2 \%$ gel agarose $(\mathrm{M}=$ Marker $100 \mathrm{bp}$, satu pita $=\hat{\delta}$ dan dua pita $=$ O $)$.
Enam puluh enam dari 69 sampel berhasil teramplifikasi oleh pasangan primer $\mathrm{TgLu}-70 \mathrm{~F}$ dan Cytb-R. Analisis genetik 66 sekuen fragmen D-loop DNA mitokondria burung pelikan menunjukkan terdapat 6 situs variabel dan kombinasi dari sekuen tersebut menghasilkan 7 haplotipe yang berbeda (Tabel 2). Mayoritas haplotipe burung pelikan yang dianalisis adalah haplotipe 1 dengan prosentase sebesar $65,5 \%$ dari total sampel, haplotipe 2 dan 3 masing-masing sebanyak $21,21 \%$ dan $7,57 \%$, sedangkan haplotipe 4, 5, 6 dan 7 hanya dimiliki $1,51 \%$ dari populasi burung pelikan (Table 2). Analisa diversitas nukleotida $0,00064 \pm 0,00010$ dan diversitas haplotipe $0,532 \pm 0,061$. Hasil tes netralitas, yaitu Tajima's D $-1,17728$ (Not significant, $\mathrm{P}>0.10$ ) dan Fu's Fs -3,246.

Tabel 1. Hasil identifikasi jenis kelamin setiap individu burung pelikan ( $P$. conspicillatus)

\begin{tabular}{|c|c|c|c|c|c|}
\hline No & Kode microchip & Jenis Kelamin & No & Kode microchip & Jenis Kelamin \\
\hline 1 & 990000000080422 & Betina & 36 & 990000000080534 & Betina \\
\hline 2 & 990000000080434 & Betina & 37 & 990000000080535 & Betina \\
\hline 3 & 990000000080437 & Betina & 38 & 990000000080536 & Betina \\
\hline 4 & 990000000080461 & Betina & 39 & 990000000080537 & Betina \\
\hline 5 & 990000000080462 & Betina & 40 & 990000000080538 & Betina \\
\hline 6 & 990000000080463 & Jantan & 41 & 990000000080539 & Betina \\
\hline 7 & 990000000080464 & Betina & 42 & 990000000080540 & Betina \\
\hline 8 & 990000000080466 & Jantan & 43 & 990000000080541 & Betina \\
\hline 9 & 990000000080467 & Betina & 44 & 990000000080542 & Betina \\
\hline 10 & 990000000080468 & Jantan & 45 & 990000000080543 & Betina \\
\hline 11 & 990000000080469 & Betina & 46 & 990000000080544 & Betina \\
\hline 12 & 990000000080470 & Betina & 47 & 990000000080545 & Betina \\
\hline 13 & 990000000080471 & Jantan & 48 & 990000000080546 & Betina \\
\hline 14 & 990000000080472 & Betina & 49 & 990000000080547 & Betina \\
\hline 15 & 990000000080473 & Jantan & 50 & 990000000080548 & Betina \\
\hline 16 & 990000000080474 & Betina & 51 & 990000000080549 & Betina \\
\hline 17 & 990000000080475 & Betina & 52 & 990000000080550 & Betina \\
\hline 18 & 990000000080476 & Jantan & 53 & 990000000080551 & Betina \\
\hline 19 & 990000000080477 & Betina & 54 & 990000000080552 & Betina \\
\hline 20 & 990000000080478 & Betina & 55 & 990000000080553 & Betina \\
\hline 21 & 990000000080479 & Betina & 56 & 990000000080554 & Betina \\
\hline 22 & 990000000080480 & Betina & 57 & 990000000080555 & Betina \\
\hline 23 & 990000000080521 & Betina & 58 & 990000000080556 & Betina \\
\hline 24 & 990000000080522 & Betina & 59 & 990000000080557 & Betina \\
\hline 25 & 990000000080523 & Betina & 60 & 990000000080558 & Betina \\
\hline 26 & 990000000080524 & Betina & 61 & 990000000080559 & Betina \\
\hline 27 & 990000000080525 & Betina & 62 & 990000000080560 & Betina \\
\hline 28 & 990000000080526 & Betina & 63 & 985120018262238 & Jantan \\
\hline 29 & 990000000080527 & Betina & 64 & 985120028844780 & Betina \\
\hline 30 & 990000000080528 & Betina & 65 & 985120027718491 & Betina \\
\hline 31 & 990000000080529 & Betina & 66 & 985120027742703 & Betina \\
\hline 32 & 990000000080530 & Betina & 67 & 985120028917643 & Betina \\
\hline 33 & 990000000080531 & Betina & 68 & 9851200278846406 & Betina \\
\hline 34 & 990000000080532 & Betina & 69 & 9851200278842438 & Betina \\
\hline 35 & 990000000080533 & Betina & & & \\
\hline
\end{tabular}




\section{PEMBAHASAN}

Identifikasi jenis kelamin pada tahap awal perkembangan hidupan liar di dalam penangkaran ex situ sangat diperlukan agar individu jantan dan betina dapat diketahui saat dilakukan pembiakan. Kesalahan dalam menentukan jenis kelamin seringkali berakibat gagal burung berkembang biak di penangkaran (Zhang et al. 2012), selanjutnya dikatakan keseimbangan rasio jenis kelamin dalam populasi kecil memainkan peran penting dalam pelestarian spesies terutama yang terancam punah (Wysocki 2006; Dybus et al. 2009).

Teknik polymerase chain reaction (PCR) dapat dilakukan terutama jika spesies burung tidak memiliki dimorfisme seksual, ciri morfometrik, dan perilaku jantan dan betina tidak jelas. Dalam konteks ini, jenis kelamin dapat ditentukan berdasarkan hasil amplifikasi PCR gen Chromodomain helicase DNA binding (CHD) (Ellegren 1996; Griffiths et al. 1996).
Perbandingan efektivitas primer $2550 \mathrm{~F} / 2718 \mathrm{R}$ (Fridolfsson \& Ellegren 1999) dan P2/P8 (Griffiths et al. 1998) untuk determinasi seksual telah dilakukan terhadap 259 ekor berbagai jenis burung Indonesia. Hasil determinasi Primer P2/ P8 $(81,8 \%)$ dan primer 2550F/2718R (100\%) (Sulandari \& Zein 2012), hal ini juga dilaporkan Khaerunisa et al. (2013). Penentuan jenis kelamin burung menggunakan metode Griffiths et al. (1998) dan Fridolfsson dan Ellegren (1999) dapat dilakukan dengan teknik PCR yang sederhana. Namun dikatakan metode Griffiths et al. (1998) terbukti juga dapat diandalkan sehubungan dengan sebagian besar spesies unggas yang diteliti (Mataragka et al. 2020). Selanjutnya dikatakan, saat menguji untuk pertama kalinya suatu spesies burung perlu dilakukan kajian pendahuluan yang akan mencakup kalibrasi metode dan penerapan pada sampel kontrol sangat disarankan sebelum memilih metode yang akan digunakan (Mataragka et al. 2020).

Tabel 2. Situs variasi dari 66 individu burung pelican meliputi haplotipe, kode sampel, persentase haplotipe, jumlah individu jantan, dan posisi nukleotida.

\begin{tabular}{|c|c|c|c|c|c|c|c|c|c|}
\hline \multirow{2}{*}{ Haplotipe } & \multirow{2}{*}{ Kode sampel } & \multirow{2}{*}{ Jumlah individu } & \multirow{2}{*}{$\begin{array}{c}\text { Jumlah } \\
\text { individu } \\
\text { jantan }\end{array}$} & \multicolumn{6}{|c|}{ Posisi nukleotida } \\
\hline & & & & 36 & 184 & 521 & 530 & $\mathbf{5 3 7}$ & 815 \\
\hline Haplotipe 1 & $\begin{array}{l}80470,62238,80466,80461,80473, \\
80476,80479,80475,80478,80467, \\
80546,80545,80560,80544,80543, \\
80547,80557,80550,80541,80551, \\
80553,80554,80558,80529,80534, \\
80538,80537,80462,80521,80533, \\
80536,80535,80527,80464,80523, \\
18491,42703,46406,42438,80437, \\
80422,80474,80477\end{array}$ & $43(65.5 \%)^{*}$ & 4 & $\mathrm{C}$ & G & $\mathrm{T}$ & $\mathrm{G}$ & $\mathrm{C}$ & A \\
\hline Haplotipe 2 & $80469,80555,80530,80524,44780$ & $5(7.57 \%)^{*}$ & - & . & . & $\mathrm{C}$ & . &. & . \\
\hline Haplotipe 3 & $\begin{array}{l}80471,80556,80552,80480,80549, \\
80548,80539,80525,80526,80522, \\
80532,80531,17643,80472\end{array}$ & $14(21.21 \%)^{*}$ & 1 & . & . & . & A & . & . \\
\hline Haplotipe 4 & 80542 & $1(1.51 \%)^{*}$ & - & $\mathrm{T}$ & . & . & . & . & . \\
\hline Haplotipe 5 & 80463 & $1(1.51 \%)^{*}$ & 1 & . & . & . & . & . & $\mathrm{G}$ \\
\hline Haplotipe 6 & 80434 & $1(1.51 \%)^{*}$ & - & . & . & . & . & $\mathrm{T}$ & . \\
\hline Haplotipe 7 & 80468 & $1(1.51 \%)^{*}$ & 1 & & A & $\mathrm{C}$ & A & & . \\
\hline
\end{tabular}

*: prosentase haplotipe pada total populasi

Tabel 3. Diversitas genetik burung Pelikan (Pelecanus conspicillatus) dalam penangkaran di Taman Margasatwa Ragunan

\begin{tabular}{|c|c|c|c|c|c|c|}
\hline $\begin{array}{l}\text { Jumlah } \\
\text { Individu }\end{array}$ & $\begin{array}{l}\text { Jumlah } \\
\text { Haplotipe }\end{array}$ & $\begin{array}{l}\text { Rata-rata } \\
\text { genetik (\%) }\end{array}$ & $\begin{array}{c}\text { jarak Diversitas } \\
\text { haplotipe }\end{array}$ & $\begin{array}{l}\text { Diversitas } \\
\text { Nukleotida (\%) }\end{array}$ & Tajima'sD (p) & $\begin{array}{c}F u ' s F s \\
(p)\end{array}$ \\
\hline 66 & 7 & 0.0642 & $0,532 \pm 0,061$ & $0,064 \pm 0,010$ & $\begin{array}{l}-1,17728 \\
(>0.01)\end{array}$ & $\begin{array}{l}-3,246 \\
(<0.05)\end{array}$ \\
\hline
\end{tabular}




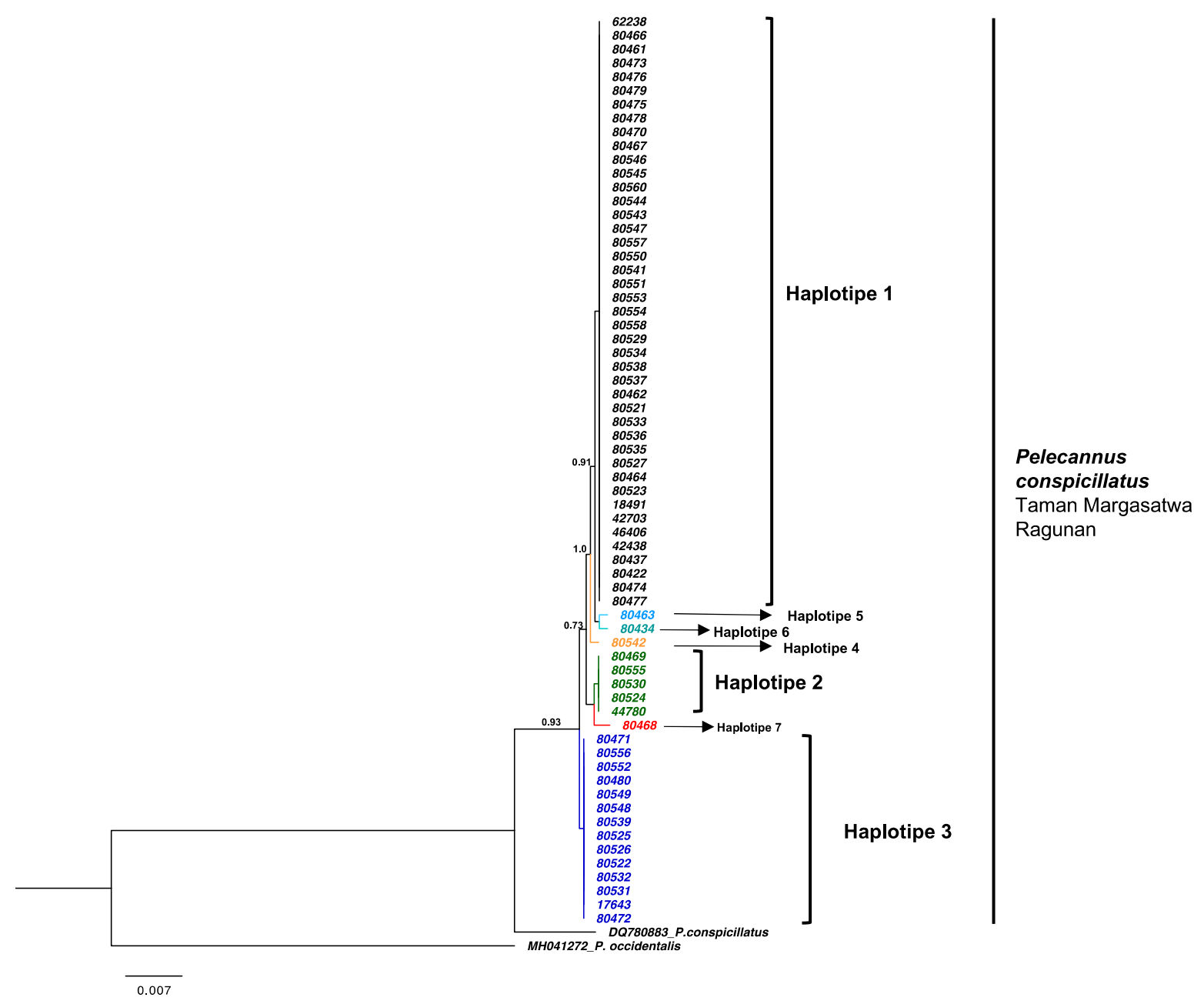

Gambar 1. Pohon Neighbor Joining 66 burung Pelican (Pelecanus conspicillatus) berbasis D-loop DNA mitokondria. Haplotipe dipresentasikan pada pohon phylo tree dengan warna berbeda; haplotipe 1 (hitam), haplotipe 2 (hijau), haplotipe 3(biru), haplotipe 4 (orange), haplotipe 5 (biru muda), haplotipe 6 (biru muda), haplotipe 7 (merah).

Di alam burung pelikan suka berteman dan hidup secara berkelompok, serta bersifat monogami selama satu musim kawin. Burung jantan dan betina dapat menyelesaikan proses pendekatan dan ikatan pasangan hanya dalam satu hari (Nelson et al. 2003). Informasi ini merupakan bagian penting dalam proses reproduksi dalam usaha melestarikan burung pelican di dalam penangkaran yang dilakukan secara terbuka dimana jantan dan betina saling dapat mencari pasangannya sendiri. Lebih lanjut dikatakan keseimbangan rasio jenis kelamin dalam populasi kecil memainkan peran penting dalam pelestarian spesies terutama yang terancam punah (Wysocki, 2006; Dybus et al., 2009). Pada semua spesies kopulasi terjadi di lokasi sarang, dimulai segera setelah berpasangan dan berlanjut selama 3-10 hari sebelum bertelur. Jantan membawa bahan sarang dan betina kemudian menumpuk material untuk membentuk struktur sederhana (Nelson et al. 2003). Oleh sebab itu sangat penting identifikasi jenis kelamin dapat segera ditentukan terutama pada burung pelikan yang sudah mencapai usia dewasa dan siap memilih pasangannya di saat musim kawin. Jika dilihat dari sex ratio yang ada maka perlu dibuat keseimbangan jantan dan betina sehingga memungkinkan di saat musim kawin masing masing individu dapat melakukan proses reproduksi. Namun demikian perlu dipertimbangkan kapasitas kandang penangkaran yang tersedia. Keberhasilan pemuliaan secara keseluruhan sangat bervariasi. Usia maksimum pelikan Australia ( $P$. conspicillatus) yang tercatat adalah 15 tahun (Johnston et al. 2015)

Data Variabilitas genetik burung pelikan yang ditangkar di Taman Margasatwa Ragunan dapat digunakan sebagai dasar melakukan 
perkawinan antara individu jantan dan betina. Hasil analisis genetik menggunakan D-Loop DNA mitokondria, terdapat 6 situs variabel dan 7 haplotipe, sedangkan diversitas haplotipe (Hd) $0,532 \pm 0,061$ dan diversitas nukleotida (pi) $0,00064 \pm 0,00010$. Nilai Hd dan pi pada populasi burung pelikan ini lebih kecil dibandingkan nilai Hd dan pi pada populasi burung waterbird di Brazilian Pantanal sebesar Hd: 0,753 $\pm 0,071$ dan pi: 0,0040 $\pm 0,002$ (Lopes et al. 2007). Hasil uji netralitas TAJIMA menunjukkan nilai negatif $(-1,17728)$ dan uji Fu dan LI menunjukkan nilai negatif $(-3,246)$ dan berbeda sangat nyata $P<0,05$ pada jarak genetik diantara individu populasi burung pelikan. Menurut SimONSEN et al. (1995), dikatakan Uji $\mathrm{Fu}$ dan Li sedikit lebih sensitif dibanding uji TAJimA. Nilai Fu's Fs negatif $(-3,246)$ dan menunjukkan nilai signifikan berbeda dari 0 merupakan indikator terjadinya populasi ekspansi yang baru terjadi atau adanya pemurnian seleksi. Nilai ini juga didukung oleh data haplotipe yang menunjukkan haplotipe umum yang ada pada populasi burung pelikan. Dari data tersebut sekuen hanya haplotipe 1 yang dominan, yaitu $65,15 \%$, kemudian diikuti haplotipe $3(21,21 \%)$, dan haplotipe $2(7,57 \%)$. Hal ini merupakan sinyal diperlukan introduksi lebih awal individu baru berupa burung jantan dan/atau betina dari populasi yang tidak mempunyai hubungan keluarga. Pada umumnya dilakukan pertukaran antar kebun binatang yang ada di Indonesia atau di luar Indonesia. Program pertukaran harus dilakukan berdasarkan kajian kesehatan untuk menjamin populasi yang ada tidak terganggu dengan masuknya individu baru. Individu dari haplotipe yang dominan dapat digunakan sebagai individu yang dipertukarkan. Cara ini diharapkan menghasilkan keturunan yang lebih bervariasi untuk menghindari sistem perkawinan keluarga (brother-sister mating).

Beberapa bukti menunjukkan ada korelasi antara penurunan keragaman genetik dan kemampuan bertahan hidup atau performa individu seperti masalah reproduksi dan daya tahan terhadap penyakit (Frankham et al. 2010). Inbreeding dan penurunan keragaman genetik dalam populasi kecil memang sulit dihindari. Namun, teknik molekuler dapat memberikan solusi yang lebih baik dan akurat yakni informasi keragaman genetik digunakan sebagai dasar perkawinan antar individu yang tersedia. Hasil penelitian yang dilakukan Jiang et al. (2005) menunjukkan diversitas dan haplotipe pada hidupan liar burung Syrmaticus ellioti elliot ternyata lebih tinggi daripada individu yang ditangkar. Oleh sebab itu perlu dilakukan pengelolaan penangkaran secara terarah berbasis data keragaman genetik dari individu jantan dan betina, sehingga dapat diatur program reproduksi agar dapat menghasilkan keturunan dengan variasi genetik yang lebih baik.

\section{KESIMPULAN}

Studi analisis genetik menggunakan D-Loop DNA mitokondria mendapatkan nilai diversitas haplotipe (Hd) 0,532 $\pm 0,061$ dan diversitas nukleotida (pi) $0,00064 \pm 0,00010$ pada populasi burung pelikan di Taman Margasatwa Ragunan.

Perlu dilakukan introduksi individu baru yang tidak mempunyai hubungan keluarga jantan dan atau betina. Individu dari haplotipe 1 yang dominan di dalam populasi dapat digunakan untuk program pertukaran antar kebun binatang atau penangkar.

\section{KONTRIBUSI PENULIS}

ABD dan MSAZ merupakan kontributor utama, berperan melakukan penelitian, penulisan dan analisis data. AM dan AP bertugas membantu kegiatan penelitian.

\section{UCAPAN TERIMAKASIH}

Terima kasih pada saudari Rini Nuraeni yang merupakan teknisi Laboratorium Genetika, Pusat Penelitian Biologi-LIPI dan semua karyawan di Taman Margasatwa Ragunan, Jakarta yang ikut melakukan pengambilan sampel darah. Penelitian ini sebagian dibiayai dari dana proyek DIPA DNA Barcoding, IPH-LIPI 2019.

\section{DAFTAR PUSTAKA}

Astuti, D. 2011. Variasi gen mitokondria Cytochrome $b$ pada dua jenis burung kakatua putih (Cacatua alba dan $C$. moluccensis). Jurnal Biologi Indonesia 7 
(2): 263-276.

Astuti, D. 2017. Struktur genetik populasi burung Betet Jawa (Psittacula alexandri alexandri) berdasarkan sekuen DNA mitokondria gen ND2. Jurnal Biologi Indonesia 13 (2): 117 - 125.

Avise, JC. 1994. Molecular Markers, Natural History and Evolution. Chapman and Hall, New York. http://dx.doi.org/ 10.1007/978 -1-4615-2381-9.

BirdLife International. 2020. Species factsheet Pelecanus conspicillatus. Downloaded from http://www.birdlife.org on19/12/2020.

Boles, WE. 1994. Pelicans. Australian Natural History. 24: 36-45.

Barros Tb., RE. Fraga, CN. Ramos, L.Tomazi 2017. Improvement of the Molecular Sexing of Parrots in the State of Bahia Acta Biologica Paranaense Curitiba. 46 (3-4): 89-107.

Çakmak E, AP. Çiğdem, \& C. Can Bilgin. 2017 Comparison of three different primer sets for sexing birds. Journal of Veterinary Diagnostic Investigation. 29(1): 59-63. https://doi.org/10.1177/1040638716675197 jvdi.sagepub.com.

Crivelli, AJ., RW. Schreiber. 1984. Status of the Pelecanidae. Biological Conservation 30 (2):147-156. ISSN 0006-3207. https:// doi.org/10.1016/0006-3207(84)90063-6.

Donald, PF. 2007.Review Adult sex ratios in wild bird populations. Ibis 149:671-692.

Dybus, A., A. Siemierz, D. Wysocki, I. Szatkowska, M. Muszyńska \& S. Guenzel. 2010. Evaluation of the applicability of polymerase chain reaction (PCR) to sex identification in Eurasian blackbirds (Turdus merula). Biological letters. 46 (1):15-20. https://doi.org/ 10.2478/v10120009-0009-x.

Frankham, R., JD. Ballou, \& DA. Briscoe. 2010. Introduction to Conservation Genetics. Cambridge University Press, Cambridge.

Fridolfsson, A. \& H. Ellegren. 1999. A simple and universal method for molecular sexing of non-ratite birds. Journal Avian Biology. 30:116-121. http://dx.doi.org/ 10.2307/3677252.

Fu, YX. \& WH. Li. 1993. Statistical test of neutrality of mutation. Genetics 133:693-
709.

Garcia, CB., JA. Insausti, JA. Gil, A. de Frutos. 2009. Comparison of different procedures of DNA analysis for sex identification in the endangered bearded vulture (Gypaetus barbatus). European Journal of Wildlife Research 55:309-312.

Geary, B., SM. Longest, K. Ottewell, SM. Lantz, ST. Walter, J. Karubian. Leberg, PL. 2017. Genetic structure of brown pelicans (Pelecanus occidentalis) in the northern gulf of Mexico in the context of human management and disturbance. PloS one 12(10),e0185309. https:// doi.org/10.1371/journal.pone.0185309

Grant, A. 2001. DNA sexing of brown kiwi (Apetryx mantelii) from feather samples DOC. Science Internal Series. Wellington: Department of Conservation.

Helander, B., F. Hailer, \& C. Vila. 2007. Morphological and genetic sex identification of white-tailed eagle Halieetus albicilla nestings. Journal Ornithology. 148:435-442.

Ito, H., A. Sudo-Yamaji, M. Abe, T. Murase, T. Tsubota. 2003. Sex identification by alternative polymerase chain reaction methods in Falconiformes. Zoology Science. 20:339-344. http:// dx.doi.org/ 10.2108/ zsj.20.339.

Jiang, PP., QL. Lang, SG. Fang, P. Ding, \& LM. Chen. 2005. A genetic diversity comparison between captive individuals and wild individuals of Elliot's Pheasant (Syrmaticus ellioti) using mitochondrial DNA. Journal of Zhejiang University SCIENCE 6B (5):413-417.

Johnston, GR., MH. Waterman, \& CE. Manning. 2015. Movement and mortality of Australian pelicans (Pelecanus conspicillatus) banded at inland and coastal breeding sites in South Australia. Pacific Conservation Biology 21, 271-276. https:// doi.org/10.1071/PC14925.

Khaerunisa I., E. Sari, M. Ulfah, Jakaria \& C. Sumantri. 2013. Avian sex determination based on chromo-helicase DNA binding (CHD) genes using polymerase chain reaction (PCR). Media Peternakan 36 (2):85-90. 
Kumar, Stecher \& Tamura. 2015. Molecular Evolutionary Genetics Analysis version 7.0 for bigger datasets.

Lee, JCI, LC. Tsai, PY. Hwa, CL. Chan, A. Huang, ASC. Chin, LC. Wang, JT. Lin, A. Linacre, \& HM. Hsieh. 2010. A novel strategy for avian species and gender identification using the CHD gene. Molecular Cell Probes 24:27-31. http:// dx.doi.org/10.1016/j.mcp. 2009.08.003.

Lee, JCI., LC. Tsai, YY. Kuan, WH. Chien, KT. Chan, CH. Wu, A. Linacre, \& HM. Hsieh. 2007. Racing pigeon identification using STR and chromo-helicase DNA binding gene markers. Electrophoresis 28:4274-4281. http://dx.doi.org/10.1002/ elps.200700063.

Li, JY., H. Chen, XY. Lan, XJ. Kong, \& LJ. Min. 2008. Genetic diversity of five Chines goat breeds assessed by microsatellite marker. Czech Journal Animal Sciences 53 (8):315- 319.

Lopes, IF., CI. Miño \& SN. Del Lama. 2007. Genetic diversity and evidence of recent demographic expansion in waterbird populations from the Brazilian Pantanal. Brazilian Journal Biology. 67(4) (Suppl.): 849-857.

Marchant, S. \& PJ. Higgins. 1990. Handbook of Australian, New Zealand \& Antarctic Birds. Volume 1, Ratites to ducks; Part B, Australian pelican to ducks. Melbourne, Oxford University Press. 737-747; plate 54.

Mataragka, A., C. Balaskas, K. Sotirakoglou, \& J. Ikonomopoulos. 2020. Comparative evaluation of the performance of the PCR assays commonly used for the determination of sex in avian species. Journal of King Saud University-Science. 32(1): 228-234. https://doi.org/10.1016/ j.jksus.

Moritz. C., WJ. Worthington, \& L. Pope. 1996. Applications of genetics to the conservation and management of Australian fauna: four case studies from Queensland. In: Smith TB, Wayne RK (eds). Molecular Genetic Approaches in Conservation. Oxford University Press. Oxford. 442456.
Naim DM, Nor SAM, Baharuddin MH. 2011. Non-invasive sex identification of the white-bellied sea eagle (Haliaeetus leucogaster) through genetic analysis of feathers. Genetic Molecular Research 10:2505-2510.

Nelson, JB, Schreiber, EA, Schreiber RW. 2003. Pelicans. In Perrins, C(ed.). Firefly Encyclopedia of Birds. Richmond Hill, Ontario: Firefly Books. pp. 78-81. doi: 10.14202/vetworld. 2019.1506-1513

Osman MA, S. Sugnaseelan, JM. Panandam, NI. $\mathrm{Ab}$ Ghani. Molecular sex iden-tification of Malaysian White-Nest Swiftlet (Aerodramus fuciphagus Thunberg, 1812). 2020. Ecology and Evolotion. 10:10440-10448. https:// doi.org/10.1002/ ece3.6699. doi: 10.14202/ vetworld.2019.1506-1513.

Purwaningrum M, HA. Nugroho, M. Asvan, K Karyanti, B. Alviyanto, R. Kusuma, \& A. Haryanto. 2019. Molecular techniques for sex identification of captive birds, Veterinary World. 12(9): 1506-1513.

Prijono, SN. M. Irham, \& D. Astuti 2017. Divergensi DNA Mitokondria pada Burung Pijantung Kecil (Arachnothera longirostra) dari Indonesia. Jurnal Biologi Indonesia 13 (2): 203-212.

Rozas, J., A. Ferrer-Mata, JC. SánchezDelBarrio, S. Guirao-Rico, P. Librado, SE. Ramos- Onsins, A. Sánchez-Gracia. 2017. DnaSP 6: DNA Sequence Polymorphism Analysis of Large Datasets. Molecular Biology Evolution 34:32993302. DOI: $10.1093 / \mathrm{molbev} / \mathrm{msx} 248$.

Rudaya, SV., OO. Katerynych, MV. Drahulian, AB. Chaplygina \& OY. Pakhomov. 2020. Sex identification of different species of wild birds using a single universal protocol to the bird sexing method based on gene polymorphism. Regulatory Mechanisms in Biosystems. 11(3): 399404. doi:10.15421/022061.

Sacchi, P., D. Soglia, S. Maione, G. Meneguz, M. Campora, R. Rasero. 2004. A noninvasive test for sex identification in short-toed Eagle (Circaetus gallicus). Molecular and Cellular Probes 18:193196. http://dx.doi.org/10.1016/j.mcp.2004.01. 002. 
Sambrook, J., SF Fritch \& T. Maniatis. 21989. Molecular cloning: a laboratory manual. Volume 1-3 second edition. Cold Spring harbor Laboratory Press, Cold spring Harbor.

Sulandari, S. \& MSA. Zein. 2012. Application of two molecular sexing methods for Indonesian bird species: implication for captive breeding programs in Indonesia. Hayati Journal Bioscience. 19(4):183-190.

Tajima F. 1989. Statistical method for testing the neutral mutation hypothesis by DNA polymorphism. Genetics. 123(3):585-595.

Voous, KH. 1962. Australian Pelican recorded in Indonesia. Emu: 67: 124.
Wysocki, D. 2006. Factors Affecting the Between-Season Divorce Rate in the Urban Populations of the European Blackbird Turdus merula in North-Western Poland. Acta Ornithologica 41(1):7178. https://doi.org/10.3161/068. 041.0101.

Yun-Xin, FU. 1997. Statistical Tests of Neutrality of Mutations Against Population Growth, Hitchhiking and Background Selection. Genetics. 147: 915-925.

Zhang, P., H. Jiabo, L. Quansheng, Z. Junxin, \& Z. Xianfeng. 2013. Sex Identification of Four Penguin Species Using LocusSpecific PCR. Zoology Biology. 32:257261. https://doi.org/10.1002/zoo.21005. 